Jurnal Ekonomi Syariah Teori dan Terapan p-ISSN: 2407-1935, e-ISSN: 2502-1508. Vol. 8 No. 2 Maret 2021: 147-158; DOI: 10.20473/vol8iss20212pp147-158

\title{
EFFECTS OF INFLATION, INTEREST, AND EXCHANGE RATE ON JAKARTA ISLAMIC INDEX 2017-2020
}

\section{PENGARUH INFLASI, SUKU BUNGA, DAN KURS TERHADAP JAKARTA ISLAMIC INDEX 2017-2020}

\author{
Theresia Putri Primartha, Nana Diana \\ Akuntansi, Fakultas Ekonomi dan Bisnis, Universitas Singaperbangsa Karawang \\ theresiaputri66@gmail.com*,nana.diana@fe.unsika.ac.id
}

\begin{abstract}
ABSTRAK
Dengan ketersediaan nya pengetahuan terkait pasar modal, Penelitian ini mencoba untuk menganalisa pengaruh inflasi, tingkat suku bunga, dan nilai tukar mata uang rupiah (Kurs) pada Jakarta Islamic Index (JII). Variabel independen yang digunakan dalam penelitian ini adalah inflasi (X1), tingkat suku bunga (X2), dan nilai tukar rupiah (X3) sedangkan variabel dependen yang digunakan adalah "Jakarta Islamic Index (JII). Tipe penelitian ini menggunakan penelitian deskriptif atau statistika inferensial dengan pendekatan kuantitatif. Populasi penelitian mencakup aspek-aspek yang mempengaruhi "Jakarta Islamic Index. Sampel yang digunakan adalah aspek aspek tersebut pada periode Januari 2017- Oktober 2020. Jenis analisis yang digunakan pada studi ini adalah analisis regresi linier berganda. Hasilnya, inflasi memberikan efek positif yang besar terhadap JII, tingkat suku bunga berpengaruh positif dan substansial terhadap JII, dan nilai tukar rupiah juga sangat memberikan pengaruh negatif terhadap JII. Penelitian ini dituntut agar bisa memberikan ilmu baru terkait, politik, sains, dan bidang lainnya.
\end{abstract}

Kata kunci: inflasi, Jakarta Islamic Index, nilai tukar, suku bunga.

\section{ABSTRACT}

With the vast body of knowledge in capital market, this study attempts to determine the effect of inflation, interest rates, and the exchange rate of the rupiah upon the Jakarta Islamic Index (JII). The independent variables in this research are inflation $(X 1)$, interest rate $(X 2)$, and rupiah exchange rate $(X 3)$, and the dependent variable are Jakarta Islamic Index $(Y)$. The research methodology used is descriptive or inferential statistics research, relying on the qualitative instrument. Hence, the population covers the factors that influence the Jakarta Islamic Index, and the sample used is those of ranges from January 2017 to October 2020. Multiple linear regression analysis is used in this study. The results showed that inflation has a significant deficiency upon the Jakarta Islamic Index (JII). The interest rate has a positive and significant effect on the Jakarta Islamic Index (JII), and the rupiah exchange rate has a significant negative impact on the Jakarta Islamic Index (JII). This research is subjected to provide more comprehensive insight into politics, social science, and other fields.

Keywords: inflation, Jakarta Islamic Index, exchange rate, interest rates.

\section{INTRODUCTION}

The development of Islamic stock transactions on the Indonesian capital market was marked when the Jakarta Islamic Index (JII) was first gaining ground on the early $20^{\text {th }}$ century. This effort was supported by the enactment of the DSN-MUI Fatwa relating to the Islamic capital market, Fatwa No.05 of 2000 that concerning Sale and Purchase. The law for stocks further strengthened in 2003 with the issuance of Fatwa No.40 of 2003, which is associated with the Capital Market and its General Guidelines in the Application of Sharia Principles in the Capital Market Sector. The Jakarta Islamic Index itself is a stock group that matches the Islamic Sharia investment criteria in the Indonesian Capital Market. In practice, the IDX conducts a JII review every 6 months, which is adjusted to the DES by BAPEPAM LK. JII itself consists of 30 liquid stocks and has a large market capitalization. Above all of that, the presence of JII is expected to be the answer for investor's wishes who want to 
invest according to sharia. In other words, JII is expected to be a guide for investors who are afraid that their investment funds will be mixed up with ribawi funds.

Table 1.

JII Stock Index Performance for 2017-2020

\begin{tabular}{|l|l|l|}
\hline No & Years & JII \\
\hline 1 & 2017 & 729.71 \\
\hline 2 & 2018 & 687.31 \\
\hline 3 & 2019 & 691.20 \\
\hline 4 & 2020 & 546.63 \\
\hline
\end{tabular}

Source: Indonesia Stock Exchange.2020

Table 1 shows the movement of the Jakarta Islamic Index (JII) index from January 2017 to October 2020. From the table above, it can be seen that in 2017 the average JII index was at 729.71 then it decreased in 2018 to 687.31 . In 2019 the JII index will increase to 691.20 and then meet the lowest value in 2020 to 546.63 .

Jakarta Islamic Index (JII) movements that decreased quite significantly is definitely influenced by various factors. According to Syahrir (1995) in Siti and Rizki (2015), several considerations that account for the development of the Islamic index have to be thought of: First, the role of macroeconomic and monetary variables such as Bank Indonesia Sharia Certificates, inflation, money supply (JUB), exchange rates, and the like. On different occasions, internal factors such as security, political situations, national economic conditions, government policies, and others play no less important part as their contributions to JII is considerable.

In this study, the macroeconomic variables used were the inflation rate, interest rate, and the IDR/USD exchange rate. Some of these variables are measured to be able to influence the fluctuation of the Islamic stock index. This topic becomes an important issue for those who want to try to invest in the capital market because it is considered to be one of the investors' considerations before investing in the capital market so that later they got no wrong in making investment decisions.

Inflation is a process by which the goods in market experience an increase in price prevailing in an economy (Sukirno, 2010). (Harianto \& Sudomo, 2001) explain that the relative increase in inflation is a negative signal for investors in the capital market. A high inflation rate will cause an increase in operating expenses on the company and it will decrease company profits. As a result, dividends distribution to shareholders will be facing a problem whether it will decrease or not be distributed because it will be retained earnings that will be used as working capital.

Table 2.

Inflation for 2017-2020

\begin{tabular}{|l|l|l|}
\hline No & Years & Inflation (\%) \\
\hline 1 & 2017 & $3.81 \%$ \\
\hline 2 & 2018 & $3.20 \%$ \\
\hline 3 & 2019 & $3.00 \%$ \\
\hline 4 & 2020 & $2.11 \%$ \\
\hline
\end{tabular}

Source: Bank Indonesia 2020

According to Bank Indonesia, "the interest rate or BI rate is a policy interest rate that reflects the attitude or monetary policy stance set by Bank Indonesia and announced to the public". Interest rates also affect the fluctuation of stock prices on the stock exchange. A significant increase in interest rates can strengthen the rupiah, but the stock index will decline because investors prefer to save in banks. If the interest rate increases, the stock price will be the same way. When the interest rate decreases, the share price will increase. Due to high-interest rates, the rupiah weakens. Conversely, if interest rates decline, investors will return to investing in the capital market because the stock index position has increased.

Table 3.

Interest Rate for 2017-2020

\begin{tabular}{|l|l|l|}
\hline No & Years & Interest rate \\
\hline 1 & 2017 & $4.56 \%$ \\
\hline 2 & 2018 & $5.10 \%$ \\
\hline 3 & 2019 & $5.62 \%$ \\
\hline 4 & 2020 & $4.35 \%$ \\
\hline
\end{tabular}


Source: Bank Indonesia 2020

Another interesting macro variable to study is the exchange rate. According to (Faizal, 2001), Exchange rate is the price of money expressed against other currencies, which can be expressed as the amount of local currency needed to buy foreign currency or vice versa. (Harianto \& Sudomo, 2001) state that the weakening of the rupiah exchange rate against other currencies (depreciation) will increase the price of importing raw materials for production. For companies that are import-oriented and transact using US dollars, the decrease within the Rupiah trade rate against the US dollar will increment the fetched of bringing in crude materials to be utilized for the process of production. This will have an effect on the decline in profits earned by the company and result in decreased dividends distributed to shareholders.

Table 4.

Exchange Rate for 2017-2020

\begin{tabular}{|l|l|l|}
\hline No & Years & Exchange rate $(\mathrm{Rp})$ \\
\hline 1 & 2017 & $\mathrm{Rp} 13.398$ \\
\hline 2 & 2018 & $\mathrm{Rp} 14.267$ \\
\hline 3 & 2019 & $\mathrm{Rp} 14.130$ \\
\hline 4 & 2020 & $\mathrm{Rp} 14.723$ \\
\hline
\end{tabular}

Source: Bank Indonesia 2020

Recently, works devoted to analyze the significance of macroeconomic variables on stock prices has been widely carried out, but many studies have resulted in different conclusions. Research conducted by (Ari \& Himawan, 2019) stated Interest Rate and Exchange Rate, rather than help, result in deficiency on the Jakarta Islamic Index. At the same time, the inflation itself has nothing to do with the Jakarta Islamic Index. Oppositely, research by (Ayu \& Leo, 2016) concluded that inflation affects the Jakarta Islamic Index (JII), and thus, the Interest Rate and Exchange Rate being beneficial to the Jakarta Islamic Index (JII).

Another research is one conducted by (Sigit \& Nila, 2018) which shows that the Interest Rate, Inflation, and the Rupiah Exchange Rate have a significant effect on the Sharia Stock Price Index (JII). Owing to that view, it becomes in line with what was conveyed by (Ardelia \& Saparila, 2018) that the macroeconomic factors that have been described, such as rates of interests, inflation, and the rupiah exchange rate will have a positive or negative influence on the Stock Index. These fluctuations will follow based on demand and supply by investors in the capital market.

Based on the explanation above, this study has come to the presence with the interest in conducting further research to determine the effect of inflation, interest rates, and the IDR / USD exchange rate on the Jakarta Islamic Index for January 2017 to October 2020, and therefore with the aim to answer following problems.

\section{Formulation of the problem}

1. Does Inflations affect the Jakarta Islamic Index?

2. Does Interest rates affect the Jakarta Islamic Index?

3. Does Rupiah Exchange Rate affect the Jakarta Islamic Index?

\section{Research purposes}

Knowing the partial effect of changes in inflation, interest rates, and the rupiah exchange rate on the movement of the Jakarta Islamic Index.

\section{Benefits of Research}

1. The results of this study are expected to strengthen previous studies related to the factors affecting the Jakarta Islamic Index.

2. The results of this study are expected to be used as additional references for further researchers to develop theories regarding the factors that affect the Jakarta Islamic Index.

3. The results of this study are expected to giving contributions to the development of the accounting literature and research. 


\section{THEORETICAL BACKGROUND AND HYPOTHESIS DEVELOPMENT}

\section{Jakarta Islamic Index (JII)}

The Jakarta Islamic Index or commonly known as JII is an Indonesian stock index that calculates the frequently changing amount of stock price index that comply with sharia law. The formation of JII cannot be separated from the cooperation between the Indonesian Capital Market (in this case PT. Jakarta Stock Exchange) and PT. Danareksa Investment Management (PT. DIM). However, only until the $3^{\text {rd }}$ of July in 2000 did JII receive considerable attention. The formation of this sharia instrument is to support the formation of the Islamic capital market which was then launched in Jakarta on March 14, 2003. The Islamic capital market mechanism imitates a similar pattern in Malaysia which is combined with conventional exchanges such as the Jakarta Stock Exchange and the Bursa Efek Surabaya effect. Each period, there are 30 (thirty) shares that are included in JII that meet the sharia criteria. JII uses a base day on January 1st, 1995 with a base value of 100 (Sutedi, 2011).

Like other stock indices, the JII index is also dynamic. In other words, the JII index is updated periodically so that it is always responsive to market movements and following existing sharia principles. According to Syahrir (1995) in Siti and Rizki (2015), a number of considerations which account for the development of the Islamic index have to be thought of: First, the role of macroeconomic and monetary variables such as Bank Indonesia Sharia Certificates, inflation, money supply (JUB), exchange rates, and the like. In different occasion, internal factors such as national economic conditions, security, political conditions, government policies, and others play no less important part as their contributions to JII is considerable.

\section{Inflation}

As cited in Sukirno (2010) in the previous section, inflation is a process by which the goods in market experience an increase in price prevailing in an economy. Inflation will increase the costs of a company. If the surplus in cost exceeds the company's revenue, then the company will mostly experience impending downfall in profit. A decrease of company profits will cause investors uninterested in investing in the company, it will turn out to be a decrease in stock prices and impact on stock returns (Tandelilin, 2010).

\section{Interest Rate}

According to Bank Indonesia (www.bi.go.id) the interest rate or BI rate is a guideline which governs the interest rate that reflects the attitude set by Bank Indonesia and widely issued to the public. The main determining factor for the determination of the BI Rate value is inflation in Indonesia. Inflation is influenced by the number of currency circulation in the country and the amount of production and public demand which results in fluctuations in prices. If inflation rises, the BI Rate will also rise, and vice versa if inflation falls, Bank Indonesia will lower the BI Rate (Ardelia \& Saparila, 2018).

\section{Exchange Rate}

The exchange rate or currency exchange rate fluctuates from a foreign currency unit within the domestic exchange money rate or an unavoidable competition between household and external money rate (Bank, 2004). Remote trade rates can be characterized as the sum of household cash required, to be specific, the sum of rupiah needed to get one outside currency unit (Sukirno, 2010).

The increase of export volume can cause depreciation of the domestic money rate against the outside currency. It added the company's profit, which rocketed the company's stock price if the worldwide demand showcase a versatile sufficient and influences the returns that investors will get (Kewal, S, 2012).

\section{Hypothesis Development}

\section{The Effect of Inflation on the Jakarta Islamic Index (JII)}

The increase in inflation can increase production costs higher than raw material prices set by the company. It can reduce the company's profitability and become bad news for the company because investors would think that investing in the capital market is not attractive and carries a higher risk. The decrease of investor interest in investing can decrease the company's stock price and can lower the stock index. 
Meanwhile, when inflation decreases or is low, it can increase profitability where production costs are reduced because raw material prices are cheap and sales prices are fixed. The development in the company's profitability will be equivalent with the rise of one's stock price since many investors want to invest in the company and will result in an increase in the stock index.

Following the statement of Fatimah (Fatimah, 2008) which describes a negative relationship between inflation and stock market performance, it is explained that an increase in inflation will reduce the real value of company demand, including dividends, thus pushing down stock prices, and vice versa. In connection with this, the development of research hypotheses can be formulated as follows

H1: Inflation has an influence on the Jakarta Islamic Index (JII)

\section{The Effect of Interest Rates on the Jakarta Islamic Index (JII)}

For the public, a high-interest rate means that the inflation rate in that country is quite high as well. The existence of high inflation will cause a reduction in the real level of public consumption because the value of money held by the public decreases and it will cause public consumption of goods produced by companies to decrease as well. It will reduce the level of company income so that it influences the level of profits in an investment. In exchange, the company's stock price will be altered (Suci, 2012). In connection with this, the development of research hypotheses can be formulated as follows

H2: Interest Rates influence the Jakarta Islamic Index (JII)

\section{The Effect of the Rupiah Exchange Rate on the Jakarta Islamic Index (JII)}

The IDR / USD exchange rate is one of the variables that can influence the movement of the stock price index on the capital market (Siti \& Rizki, 2015). The depreciating IDR / USD exchange rate will have a different impact on import or export companies. Companies that use imported raw materials will bear higher costs than before due to the weakening of the domestic currency. If the increase in costs is greater than the current net worth, the gained profit will decline which will result in a decrease in dividends that will be received by investors and turns out in a decrease in share prices.

For export companies or companies that have foreign receivables, the depreciating exchange rate will certainly have a positive impact where the level of exports will increase. Increasing exports will certainly increase the company's profitability and increase dividends received by investors. The high dividends that will be received will certainly attract investors to invest and will increase the share price and emotional stock index. The opposite situations will happen when the rupiah exchange rate appreciates or strengthens (Siti \& Rizki, 2015). From the explanation above, the development of the research hypothesis can be formulated as follows

H3: The IDR / USD Exchange influences the Jakarta Islamic Index (JII)

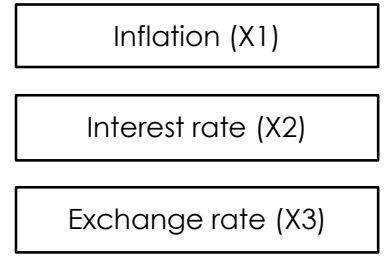

Source: Author, 2020

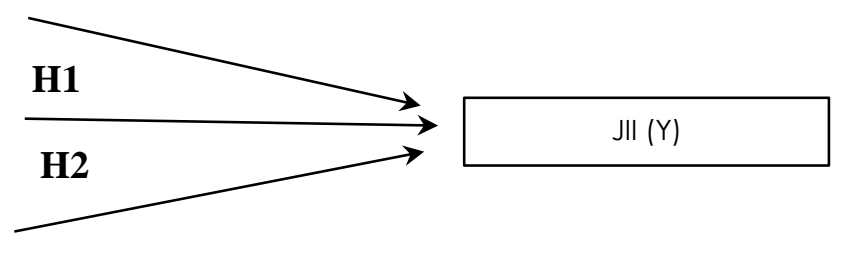

H3

Figure 1.

Framework

\section{Research Hypothesis}

The research hypothesis that formulated based on the explanation of framework and theories can be seen down below

H1: Inflation affects the Jakarta Islamic Index.

H2: Interest Rate affects the Jakarta Islamic Index.

H3: Exchange rate affects the Jakarta Islamic Index. 


\section{RESEARCH METHODOLOGY}

The collected data will be tested quantitatively by using descriptive or inferential statistics so that it can be concluded the hypothesis is proven or not. This research is structured to prove the hypothesis that there are macroeconomic factors such as inflation, interest rates, and the rupiah exchange rate which affect the stock price index on the Jakarta Islamic Index for January 2017October 2020.

\section{Variable Identification}

As has been stated in the previous section, the main variable in this study is inflation interest rates, and rupiah exchange rates. The dependent variable is the stock price index in the Jakarta Islamic Index.

\section{Operational definition}

Operational definition according to (Sugiyono, 2014) is the determining factor of nature to be studied so that it becomes a measurable variable. The operational definition describes the specific means used to research and operate constructs, allowing future studies to construct measurements in the same way or formulate better means of measuring. The operational definitions of JII, Inflation, Interest Rates, and Rupiah Exchange Rates are as follows:

\section{Jakarta Islamic Index}

First launched on the Indonesian capital market in the early $20^{\text {th }}$ Century, The Jakarta Islamic Index is a series of stock markets which complies with sharia law index and plays part in Indonesia's economy (www.idx.co.id). JII shows a composite index of shares listed on the Indonesia Stock Exchange and also issued by the Indonesia Stock Exchange where the business activities of the share issuing company are based on sharia law, in points.

2. Inflation

Inflation is the rise in the entire market value of goods, sometimes this amount increase is prolonged (Mankiw, 2005). The inflation indicator used in this study is inflation rate which can be obtained through the official website of Bank Indonesia www.bi.co.id which is expressed as a percentage.

3. Interest Rate

According to Bank Indonesia (www.bi.go.id) the interest rate or BI rate is a guideline which governs the interest rate that reflects the attitude set by Bank Indonesia and widely issued to the public. This variable is measured by the, which is the policy interest rate that reflects the attitude or monetary policy stance set by Bank Indonesia and announced to the public. In this study, the interest rate uses the BI Rate 7 days which can be obtained through the official website of Bank Indonesia www.bi.co.id which is expressed as a percentage.

4. Exchange Rate

Foreign exchange rates can be defined as the amount of domestic money needed, namely the amount of rupiah needed to obtain one unit of foreign currency (Sukirno, 2010). The foreign exchange rate is determined in the foreign exchange market, which is the market in which various currencies are traded. In this study, the rupiah exchange rate against USD is used and the indicator of the exchange rate used in this study is the middle rate, which is the sum of the selling rate and the buying rate divided by two.

\section{Types and Sources of Data}

The data used is secondary data in the form of a summary of the Jakarta Islamic Index data which is drafted on the Indonesia Stock Exchange (BEI) which has been issued during the research period. According to Sugiyono (2017), secondary data is an instrument that does not immediately give evidence to data collectors. It subsequently supports chief data such as books, literature, and reading supports and related to this research.

In this study, the three independent variables, such as inflation, interest rates, and rupiah exchange rates, were obtained from the summary listed on the official website of Bank Indonesia, bi.go.id. Meanwhile, the dependent variable, such as the Jakarta Islamic Index, is obtained from the official website of the Indonesia Stock Exchange, idx.co.id. 


\section{Population and Sample}

The population is the whole symptom or unit to be investigated (Prasetyo \& Lina, 2012). The population in this study is of all e Islamic stocks from Jakarta Islamic Index (JII) during January 2017-October 2020.

The sample is a portion of the populace part of the population, and it could be a strategy that's as it were a portion of the populace taken and utilized to determine the desired characteristics and characteristics of the population (Nazir, 2003).

\section{Data Analysis Method}

According to Sugiyono (2017), the data analysis method in quantitative research is an activity of grouping information depending on variables and types of respondents and showing data from each variable to be examined, then attempting a calculation in order to solve a challenge in formulation to test the proposed hypothesis. The method used to process data in this research is SPSS version 25 software as a tool to regress the formulated model.

\section{Classic Assumption Test}

\section{Normality Test}

One of the multiple regression testing requirements is the data should be normally distributed. According to (Ghozali, 2011), the residual test of normality's purpose is to examine whether there is a normal distribution in the model (regression) of the confounding or residual variables. The data is normally categorized if the probability value is up to $0.05(>0.05)$.

2. Heteroscedasticity Test

This test's purpose is to know whether there is an inequality of variance from a residual to another observation in the regression model. The decisions made on the heteroscedasticity test are based on:

If the probability value $>0.05$, there is no heteroscedasticity

If the probability value $<0.05$, there is heteroscedasticity

3. Multicollinearity Test

When the independent variables correlate, then it's called multicollinearity. This test's purpose is to know whether there are similarities between those independent variables or not. Multicollinearity testing in this study uses the Variance Inflation Factor (VIF). The used requirement is if the centered VIF value is smaller than 10, then there are no multicollinearity symptoms.

4. Autocorrelation Test

This test's purpose is to test whether there is no correlation from observation to another that is sorted by time. A regression model can be said as a good model if there is no autocorrelation. The data is categorized as free from autocorrelation if the Durbin-Watson value is in the range -2 to 2 . If the Durbin-Watson value is outside this range but is between -4 and 4 , then the data is categorized as no-decision.

\section{Data Analysis Technique}

1. Determination Coefficient Test (Adjusted R Square)

The test purpose is to assess the goodness-fit of the regression model. The interchangeable relations (R2) measures how effective the model can explain model variations in explaining variations in the dependent variable.

2. Hypothesis Test

t Test

The t-test is carried out to assess if the independent variable can explain the dependent variable well separately, provided that if the sig value is $<0.05$ and $t$-count is greater than the table value so that the hypothesis is accepted. 


\section{RESULTS AND DISCUSSIONS}

\section{Classic Assumption Test}

\section{Normality Test}

The results of the test of normality are shown in table 5:

Table 5.

Normality Test

"One-Sample Kolmogorov-Smirnov Test"

\begin{tabular}{llr}
\hline "N" & & Unstandardized Residual" \\
\hline "Normal Parameters, & "Mean" & 46 \\
\cline { 2 - 3 } & "Std. Deviation" &, 0000000 \\
\hline "Most Extreme Differences" & "Absolute" & 33,93151632 \\
& "Positive" &, 098 \\
\hline "Negative" &, 098 \\
\hline "Test Statistic" & &,- 080 \\
\hline "Asymp. Sig. (2-tailed)" & &, 098 \\
\hline
\end{tabular}

Source: SPSS 25 test results.2020

The Kolmogorov Smirnov One-Sample Table stipulates that if the data is well delivered, the Asymp-Sig (2-tailed) value is no little than 0.05. In table 5, the significance value of the Asymp-Sig (2-tailed) is 0.200 and greater than 0.05 . This shows the normality assumption is fulfilled or the data is normally distributed.

The next way takes the work of analyzing on the Normal Probability Plots image as follows:

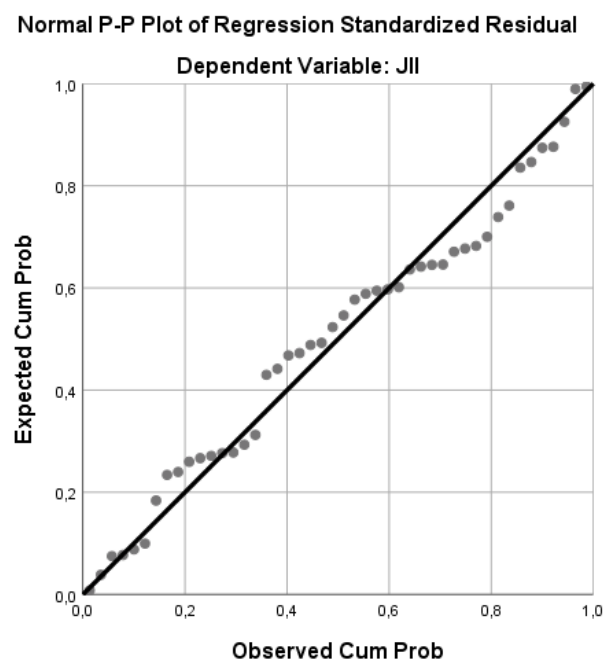

Source: SPSS 25 Test, Figure 2. P-P PLOT Normality Test. 2020

Figure 2.

Histogram Graph

From the test results in Figure 2 with the output in the form of a graph, it is evident that all the dots were positioned around the edge of straight line and are parallel to the diagonal line. This shows the normality assumption is fulfilled or the residual information has generally been delivered.

\section{Multicollinearity Test}

The results of multicollinearity test are shown in table 6:

Table 6.

Multicollinearity Test

Coefficients $^{\mathrm{a}}$

\begin{tabular}{|l|l|l|l|}
\hline \multirow{2}{*}{ “Model" } & \multicolumn{2}{|c|}{ Collinearity Statistics } \\
\cline { 2 - 4 } & \multicolumn{2}{|c|}{ "Tolerance" } & \\
\hline \multirow{2}{*}{1} & "(Constant)" &, 591 & 1,693 \\
\cline { 2 - 5 } & Inflation &, 868 & 1,152 \\
\hline
\end{tabular}


Exhange rates , 591

a. Dependent Variable: JII

Source: SPSS 25 test results. 2020

Based on table 6, we knew that the tolerance value for the inflations variable is 0.591 , the interest rate variable is 0.868 , and the exchange rate variable is 0.591 , which means that the tolerance value is $>0.100$, and the VIF value for the inflation variable is 1.693 , the interest rate variable is 1.152 , and the exchange rate variable is 1.693 which means this value is less than 10 . So the conclusion is there is no multicollinearity between the independent variables.

\section{Heteroscedasticity Test}

The test heteroscedasticity results are shown in Figure 3:

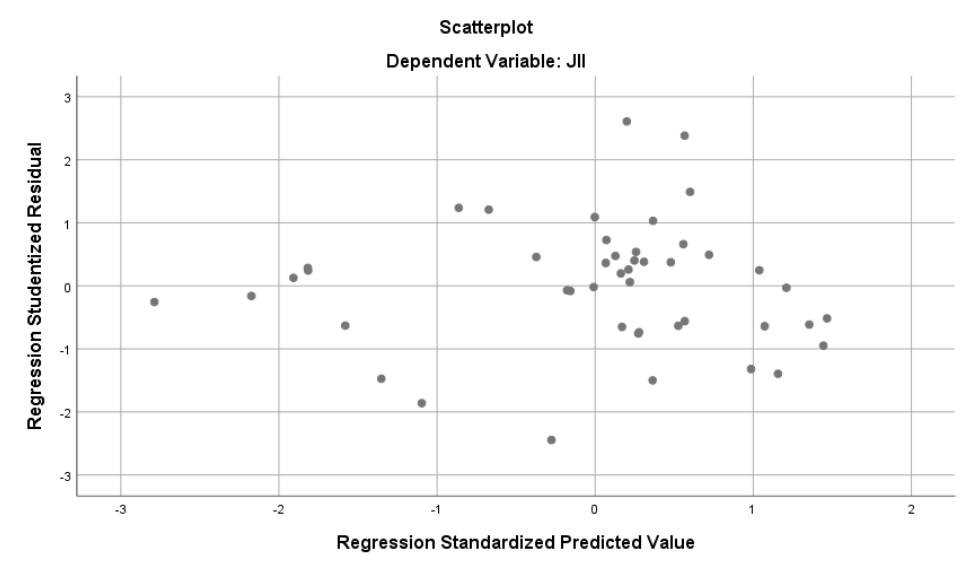

Source: SPSS 25 test results, Figure 3. Normality Test. 2020

Figure 3.

Normality Test

From Figure 3, we can see that the dots spread below also above the 0 on the $\mathrm{Y}$ axis has abstract arrangement. Therefore, the conclusion is that the regression model has no heteroscedasticity.

\section{Autocorrelation Test}

The results of autocorrelation test are shown in Table 7:

Table 7.

Autocorrelation Test

"Model Summaryb"

"Model"

"Durbin-Watson"

Source: SPSS 25 test results.2020

From the results of tests carried out with predetermined data, it is known that the DW value is 0.815 with $\mathrm{k}$ as much as 3 (number of exogenous variables) and $\mathrm{N}$ as much as 46 (amount of data). then the DW value is at $-2<0.815<2$ which indicates there is no autocorrelation.

\section{Multiple Linear Regression Analysis}

The value of multiple linear regression can be seen from table 8 below,

Table 8.

"Multiple Linear" Regression

Coefficients $^{\mathrm{a}}$

\begin{tabular}{|c|c|c|c|c|}
\hline \multirow{2}{*}{\multicolumn{4}{|c|}{ Coefficients $^{\mathrm{a}}$}} & \multirow{3}{*}{$\begin{array}{c}\text { "Standardized Coefficients } \\
\text { Beta" }\end{array}$} \\
\hline & & & & \\
\hline \multicolumn{2}{|c|}{ "Model" } & “B” & "Std. Error" & \\
\hline \multirow[t]{4}{*}{1} & "(Constant)" & 1475,008 & 161,633 & \\
\hline & Inflation & 3442,682 & 961,556 & ,326 \\
\hline & Interest rates & 2901,309 & 826,600 & ,263 \\
\hline & Exhange rates &,- 075 & ,011 &,- 636 \\
\hline
\end{tabular}

a. Dependent Variable: JII

Source: SPSS 25 test results. 2020 
Based on table 8, the equation of multiple linear regression can be obtained as follows: $\mathrm{Y}=$ $1475,008+3442,682(\mathrm{X} 1)+2901,309$ (X2) -0.075 (X3). Where the endogenous variable is the JII index (Y) and the exogenous variables are Inflation (X1), Interest Rates (X2), and Exchange Rates (X3). From the equation above, it can be concluded that:

1. A fixed amount of 1475,008 indicates that if inflation, interest rates, and exchange rates are zero or constant, the JII Index value is 1475,008 .

2. The inflation regression coefficient of 3442,682 has a coefficient that is in line with the JII. it means each increase in inflation will cause 3442,682 increase in the JII. Vice versa, each decrease of one unit of inflation causes a decrease in the JII with the assumption that the other variables are constant.

3. The interest rate regression coefficient of 2901,309 has a coefficient of the same relationship with the JII. Every one-unit advancement in the BI interest rate will cause an increase in the JII by 2901,309 Likewise, every unit decrease in the BI interest rate will further make a decline in the JII considering the view that the others are in a fixed state.

4. The coefficient of exchange rate regression which is -0.075 has a coefficient that is not in line with the JII. Each one-unit increase in the exchange rate causes a decrease in the JII by - 0.075. Vice versa, each decrease of one unit from the exchange rate, causes an increase in the JII by 0.075 units, assuming that the other variables are constant.

t test

The $\mathrm{t}$ test results are shown in table 9 below:

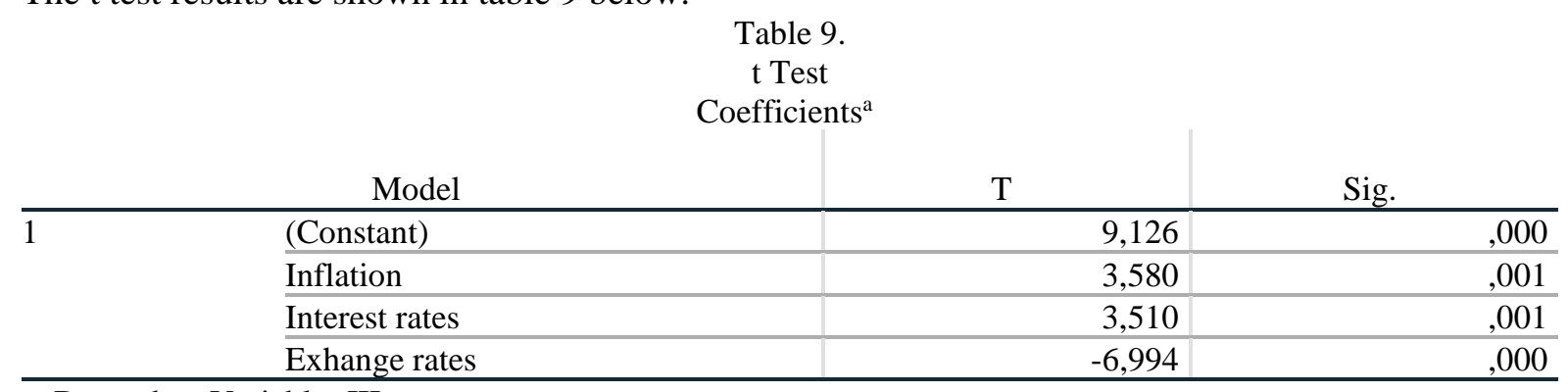

a. Dependent Variable: JII

Source: SPSS 25 test results. 2020

1. The $t$ count of the Inflation variable is 3,580 with 0.000 as a significance. The considerable amount is no greater than the predetermined significance amount of 0.05 indicates the inflation has a significant contribution to the JII.

2. The interest rate variable has a t count of 3,510 with a significance of 0,000 . The considerable amount is no greater than the predetermined significance amount of 0.05 indicates the interest rate variable has a significant contribution to the JII.

3. With a significance value of 0.000 , the exchange rate reached $-6,994$ as it count. Also, the smaller significance than the probability value indicates the exchange rate has a partial and significant effect on the JII. A negative value indicates that the exchange rate is associated with the opposite direction to the JII index.

\section{Coefficient of Determination}

We can see the coefficient of determination from the table below:

Table 10.

Coefficient of Determination

Model Summary"

\begin{tabular}{|c|c|c|c|c|}
\hline "Model" & "R" & "R Square" & Adjusted R Square & $\begin{array}{l}\text { "Std. Error of the } \\
\text { Estimate" }\end{array}$ \\
\hline 1 & $891^{\mathrm{a}^{\mathrm{n}}}$ &, 795 &, 780 & 35,122 \\
\hline
\end{tabular}

a. Predictors: (Constant), Exhange rates, Interest rates, Inflation

b. Dependent Variable: JII

Source: SPSS 25 test results 
The R. Square result value is 0.795 or $79,5 \%$, meaning that the independent variable or Jakarta Islamic Index can be explained by inflation, interest rates, and the rupiah exchange rate of $79,5 \%$. Thus, the rest $20,5 \%$ account for undefined instances besides those in this study.

\section{Discussions}

1. Effects of Inflation on the JII index

From the results above, it's known that there's a significant influence between inflation on the stock price index of JII. This shows that changes in the JII stock price index can be influenced by changes in inflation that occur in the Indonesian economy.

The results are in line with the results of research conducted by (Mulyani, 2014), show that there is a significant positive effect between inflation and JII. Therefore, if inflation increases, the JII will also increase. Vice versa, if inflation decreases, the JII will also decrease. Then based on the explanation of (Kewal, S, 2012) which states that inflation is a tendency of price increases that occur continuously. If inflation increases, it will reduce the level of real income that investors get from investing because stock prices increase. On the other hand, if inflation in a country decreases, the stock price will also decrease because the risk of purchasing power of money and the risk of decreasing real income also decreases.

2. Effect of interest rates on the JII index

Changes in interest rates may result in fluctuations of the price in stock. This is supported by the theory described by (Tandelilin, 2010) which explains that high-interest rates negatively signal stock prices where investors will tend to invest and move their investments both in deposits and its counterpart. From the theory and results of previous research used as literature in this study, most of them concluded that interest rates negatively affected the capital market. However, this study found things that were contrary to the theory and previous research that the interest rate had a positive influence on the stock price index in the capital market. Previous research that supports this study's outcomes is research conducted by (Amin, 2012) which concluded that interest rates indicate an important influence on the stock price.

Referring to the results of this study, interest rates which are prohibited in Islam and should not be a factor in investing for Muslim investors in fact still have an influence on the movement of the JII index number. In other words, interest rates remain a reference for investing both conventional and Muslim investors.

3. The Effect of Exchange Rates on the JII index

Mishkin's portfolio theory (Mishkin, 2008) states that the demand for securities is influenced by interest rates, wealth, inflation, and exchange rates. The final results of hypothesis testing in this study found that the rupiah exchange rate variable had a remarkable unfavorable effect on the movement of Indonesian Sharia Stock Index. This research product is expected to have the same conclusion as those of previous studies presented by (Rusbariandi et al., 2012) and (Vejzagic et al., 2013). This study follows the existing theory that when the exchange rate changes, the JII will decrease. Vice versa, when the exchange rate decreases, the JII will increase. This indicates that investors use the rupiah exchange rate factor as a benchmark to decide to invest in shares on the IDX partially.

\section{CONCLUSIONS}

After a long process of analysis and discussion, we can conclude that:

1. The inflation rate significantly affects the Jakarta Islamic Index (JII) for January 2017-October 2020 .

2. Interest rates have a significant effect on the Jakarta Islamic Index (JII) for January 2017-October 2020.

3. The exchange rate has a significant negative effect on the Jakarta Islamic Index (JII) for the January 2017-October 2020 period. 


\section{REFERENCES}

Amin, M. Z. (2012). Pengaruh tingkat inflasi, suku bunga SBI, nilai kurs dollar (USD/IDR) dan indeks Dow Jones (DJIA) terhadap pergerakan indeks harga saham gabungan di bursa efek Indonesia (BEI) (Periode 2008-2011). Jurnal Ilmiah Mahasiswa FEB, 1(1), 1-17.

Ardelia, R. H., Worokinasih, S. (2018). Pengaruh inflasi, suku bunga, dan nilai tukar rupiah terhadap indeks harga saham gabungan (Studi pada Bursa Efek Indonesia Periode 2013-2017). Jurnal Administrasi Bisnis, 60(2), 102-110.

Ari, A., Sutanto, H. A. (2019). Pengaruh indikator makro dan harga emas dunia terhadap indeks harga saham syariah (Jakarta Islamic Index). ECONBANK: Journal of Economics and Banking, $1(1), 26-38$.

Ayu, T. U., Herlambang, L. (2016). Pengaruh variabel makro ekonomi terhadap indeks jakarta islamic index (jii) periode januari 2010 hingga november 2015. Jurnal Ekonomi Syariah Teori dan Terapan, 3(1), 70-84.

Bank Indonesia. (2004). Surat edaran Bank Indonesia nomor 6/23/DPNP perihal sistem penilaian tingkat kesehatan bank.

Bank Indonesia. (2020). Statistik inflasi, kurs, BI rate 2017-2020. Diakses dari http://www.bi.go.id

Faizal, M. (2001). Manajemen keuangan internasional. Depok: Salemba Empat.

Fatimah, A. L. (2008). Pasar Modal, Jakarta. Depok: FEUI.

Ghozali, I. (2011). Aplikasi analisis multivariate dengan program SPSS. Semarang: Badan Penerbit Universitas Diponegoro.

Kewal, S, S. (2012). Pengaruh inflasi, suku bunga, kurs, dan pertumbuhan PDB terhadap indeks harga saham gabungan. Jurnal Economia, 8(1), 53-64.

Mankiw, G. N. (2005). Teori makro ekonomi. Jakarta: Erlangga.

Mishkin, F. S. (2008). Ekonomi uang, perbankan, dan pasar keuangan. Depok: Salemba Empat.

Mulyani, N. (2014). Analisis pengaruh inflasi, suku bunga, nilai tukar rupiah, dan produk domestik bruto terhadap Jakarta Islamic Index. Jurnal Bisnis dan Manajemen Eksekutif, 1(1).

Nazir, M. (2003). Metode penelitian. Jakarta: Ghalia Indonesia.

Prasetyo, B., \& Lina, M. J. (2012). Metode penelitian kuantitatif. Jakarta: Raja Grafindo Persada.

Rusbariandi, Septian, Prima, \& Dkk. (2012). Analisis pengaruh tingkat inflasi, harga minyak dunia, harga emas dunia dan kurs rupiah terhadap pergerakan Jakarta Islamic Index di bursa efek Indonesia. Prosiding Seminar Nasional Forum Bisnis \& Keuangan 1, 724-740.

Sanjaya, S., Pratiwi, N. (2018). Pengaruh tingkat suku bunga, kurs dan inflasi terhadap Jakarta Islamic Index (JII). Jurnal Ekonomi dan Bisnis Islam, 3(1), 47-58.

Suciningtyas. S.A., Khoiroh, R. (2015). Analisis dampak variabel makro ekonomi terhadap indeks saham syariah indonesia (ISSI). Conference In Business, Accounting, And Management (CBAM), 2(1), 398-412.

Sugiyono. (2014). Metode penelitian pendidikan pendekatan kuantitatif, kualitatif, dan $R \& D$. Bandung: CV. Alfabeta.

Sugiyono. (2017). Metode penelitian pendidikan pendekatan kuantitatif, kualitatif, dan $R \& D$. Bandung: CV. Alfabeta.

Sukirno, S. (2010). Makroekonomi: Teori pengantar. Jakarta: Rajawali Pers.

Sutedi, A. (2011). Pasar modal syariah: Sarana investasi keuangan berdasarkan konsep syariah. Jakarta: Sinar Grafika.

Tandelilin, E. (2010). Portofolio dan investasi: Teori dan aplikasi. Yogyakarta: Kanisius.

Vejzagic, Mirza, \& Zarafat, H. (2013). Relationship between macroeconomic variables and stock market index: Co-integration evidence from FTSE bursa malaysia hijrah shariah index. Asian Journal of Management Science and Education, 2(4), 93-108. 